\title{
Etika Komunikasi Sebagai Kontrol Kesalehan Virtual dalam Perilaku Bermedia Masyarakat di Era Digital
}

\author{
A. Fikri Amiruddin Ihsani ${ }^{1}$, Novi Febriyanti ${ }^{2}$ \\ ${ }^{1}$ Komunikasi dan Penyiaran Islam, Pascasarjana, Universitas Islam Negeri Sunan Ampel, \\ Jl. Jend. A. Yani 117, Surabaya, 60237 \\ ${ }^{2}$ Ekonomi Syariah, Pascasarjana, Universitas Islam Negeri Sunan Ampel, \\ Jl. Jend. A. Yani 117, Surabaya, 60237
}

Penulis untuk korespondensi/E-mail: fikriamiruddin27@gmail.com

\begin{abstract}
Abstrak
Penelitian ini membahas mengenai etika komunikasi sebagai kontrol kesalehan virtual dalam perilaku bermedia masyarakat di era digital. Adapun tujuan dari penelitian ini adalah untuk mendeskripsikan, menjelaskan, dan mengetahui peran etika komunikasi sebagai kontrol kesalehan virtual dalam perilaku bermedia masyarakat di era digital. Konsep etika komunikasi yang digunakan berdasarkan perspektif Haryatmoko dan dilengkapi oleh teori tindakan komunikasi Habermas. Penelitian ini menggunakan metode penelitian kualitatif dengan pendekatan deskriptif. Teknik pengumpulan data yang digunakan adalah observasi dan dokumentasi. Data-data yang berhasil diperoleh kemudian dianalisis, dibandingkan, dan dipadukan sehingga terbentuk sebuah hasil kajian yang sistematis, padu, dan utuh. Dalam penelitian ini diperoleh hasil bahwa etika komunikasi merupakan seperangkat norma, nilai, atau ukuran tingkah laku yang baik dalam aktivitas komunikasi. Dalam hal ini, etika komunikasi sebagai kontrol kesalehan virtual dalam perilaku bermedia masyarakat di era digital ini dimaksudkan untuk menjamin pada tercapainya sifat-sifat umum akan norma-norma yang dapat diterima dalam kehidupan masyarakat. Selain itu, menjamin pada otonomi individu melalui kemampuan emansipatoris sehingga menghasilkan pembentukan kehendak bersama melalui perbincangan yang rasional. Dengan demikian, etika komunikasi merupakan sebuah upaya untuk mengontrol proses komunikasi agar tercipta stabilitas sosial dalam masyarakat yang plural di era digital.
\end{abstract}

Kata Kunci: Etika; Komunikasi; Kesalehan; Virtual; Digital.

\begin{abstract}
This study discusses communication ethics as control of virtual piety in public media behavior in the digital era. The purpose of this study is to describe, explain and determine the role of communication ethics as control of virtual piety in public media behavior in the digital era. The concept of communication ethics used is based on Haryatmoko's perspective and is complemented by Habermas's theory of communication actions. This research uses qualitative research methods with a descriptive approach. The data collection techniques used were observation and documentation. The data that has been successfully obtained are then analyzed, compared, and combined to form a systematic, coherent, and complete study result. In this study, the results show that communication ethics is a set of norms, values, or a measure of good behavior in communication activities. In this case, communication ethics as control of virtual piety in public media behavior in this digital era is intended to ensure the attainment of general characteristics of acceptable norms in people's lives. Besides that, it guarantees individual autonomy through emancipatory abilities to result in the formation of a common will through rational conversation. Thus, communication ethics is an effort to control the communication process to create social stability in a pluralistic society in the digital era.
\end{abstract}

Keywords: Ethics; Communication; Piety; Virtual; Digital. 


\section{PENDAHULUAN}

Di era saat ini, akibat cepatnya perkembangan teknologi dan ilmu pengetahuan, termasuk di dalamnya perkembangan ilmu-ilmu sosial kemanusiaan serta media dan teknologi informasi komunikasi yang begitu pesat terutama media sosial secara relatif mendekatkan jarak perbedaan budaya antara satu wilayah dengan wilayah lain. Maka dari itu, pada tahun 2009 media sosial menjelma menjadi sarana informasi yang cukup potensial di Indonesia (Fahmi, 2011). Naiknya pengguna media sosial di Indonesia berlaku pada aplikasi jejaring situs pertemanan dan informasi. Dalam hal ini, hampir setiap masyarakat di Indonesia mempunyai dan mengakses media sosial yang ada. Media sosial ini juga bermacam-macam antara lain Facebook, Twitter, Instragram, Path, dan lain sebagainya (Nurudin, 2012).

Proses sosialisasi yang dilakukan dalam media sosial, haruslah memperhatikan etika dalam berkomunikasi. Hal ini cukup penting mengingat segala aktivitas masyarakat di media sosial dapat berdampak buruk dalam kehidupan manusia, baik secara langsung maupun tidak langsung. Komunikasi yang dilakukan di media sosial haruslah komunikatif dan sopan. Sebagai manusia dalam kehidupan sehari-hari tidak akan terlepas dari proses sosialisasi (Nasrullah, 2015). Komunikasi selalu menjadi aktivitas utama manusia, mulai dari bangun tidur hingga tidur kembali, entah itu komunikasi formal maupun komunikasi non-formal. Media sosial cukup mempengaruhi kehidupan seseorang, dengan demikian masyarakat harus mampu menyikapi dengan bijak sehingga kemudian tidak melupakan kewajiban pada kehidupan nyata. Selain itu, manusia pun harus memenuhi etika dalam penggunaan media sosial, sehingga mendapat hal baik dan positif, minimal sebagai hiburan dan sumber informasi faktual.

Selain itu, proses evolusi yang terjadi di bidang teknologi maupun inovasi internet menyebabkan tidak hanya memunculkan media baru saja. Namun, berbagai macam aspek kehidupan manusia seperti komunikasi atau interaksi juga mengalami pergeseran budaya dan lunturnya norma-norma kesantunan dalam segala hal, sehingga memberi efek buruk bagi masyarakat. Sehingga bukan kesantunan berbahasa yang terjalin, melainkan kekerasan fisik atau simbolik (Suseno, 1993). Nilai-nilai yang terbentuk dalam masyarakat terdapat beberapa kaidah yang memiliki tujuan untuk mengatur tata cara berkomunikasi antara sesama manusia tanpa menyakiti hati dan menjunjung tinggi etika sebagai suatu tanda penghargaan terhadap lawan bicara. Namun, terkadang cara berkomunikasi, pemakaian kata atau kalimat yang dianggap sebuah etika, dapat pula berakibat pada sesuatu yang tidak menyenangkan dan menimbulkan kesalahpahaman antara sesama manusia (Kismiyati, 2010).

Dunia seolah-olah tidak memiliki batasan, sehingga pada akhirnya tidak ada kerahasiaan yang dapat ditutupi. Masyarakat dapat mengetahui aktivitas, kegiatan maupun peristiwa apa saja melalui media sosial. Dunia virtual seperti media sosial merupakan revolusi besar yang mampu mengubah perilaku manusia dewasa ini. Pada akhirnya realitas menjadi bersifat virtual dan maya yang harus diadaptasi dan diintegrasikan dalam kajian ilmu pengetahuan kontemporer. Sehingga diperlukan sebuah kontrol atau pengendalian agar kesalehan virtual dan perilaku bermedia masyarakat ini dapat terjaga, menghibur, serta menginformasi.

Beberapa penelitian terdahulu terkait dengan penelitian ini antara lain penelitian mengenai implementasi etika komunikasi Islam dalam tindakan sosial netizen di media sosial twitter yang menjelaskan bahwa dengan adanya penerapan etika komunikasi Islam yang baik di media sosial diharapkan dapat mencegah dampak negatif dalam penggunaan media sosial (Ihsani, 2020). Berikutnya penelitian mengenai komunikasi kelompok dalam komunitas virtual yang menjelaskan bahwa dalam media sosial setiap individu terlibat dalam ruang virtual yang membentuk modal jaringan sosial dan modal pengetahuan yang harus dijaga kepercayaan dan keamanannya dengan selalu memperhatikan etika komunikasi (Nurhaliza, 2020). Selain itu, ada juga penelitian mengenai etika komunikasi islami yang menjelaskan bahwa dalam kegiatan komunikasi harus dilakukan berdasarkan nilainilai etika yang dianut dalam sebuah masyarakat, hal ini dimaksudkan agar komunikasi yang dilakukan dapat terjalin dengan menyenangkan, memberi kebaikan, dan memberi manfaat bagi pelaku komunikasi (Susanto, 2016). 
Dengan demikian, karya tulis ini membahas mengenai implementasi etika komunikasi dalam mengontrol atau mengendalikan kesalehan virtual dalam perilaku bermedia masyarakat di era digital. Selain itu, akan sedikit membahas mengenai jenis perilaku bermedia sosial yang berkembang dalam kehidupan masyarakat dikarenakan saling terkait satu sama lain. Adapun tujuan dari penelitian ini adalah untuk mengetahui dan mendeskripsikan peran etika komunikasi sebagai kontrol kesalehan virtual dalam bermedia sosial masyarakat. Karena itu, diharapkan karya tulis ilmiah ini dapat memberi pemahaman mengenai peran etika komunikasi secara komprehensif. Kemudian juga sebagai sumbangan pemikiran dalam khazanah keilmuan masyarakat guna pengembangan ilmu terkait.

Selain itu, karya tulis ilmiah ini dapat memberi informasi tambahan atau mungkin pembanding bagi peneliti atau penulis lain dalam persoalan terkait dan sebagai pengingat bahwa etika komunikasi itu sangat penting dalam kontrol kesalehan virtual perilaku bermedia masyarakat di era digital. Apalagi di era digital ini berbagai perilaku bermedia masyarakat berkembang begitu pesatnya.

\section{Etika Komunikasi}

Dalam kehidupan bermasyarakat terdapat suatu sistem yang mengatur tata cara manusia bergaul. Tata cara pergaulan untuk saling menghormati biasa dikenal dengan sebutan sopan santun. Tata cara pergaulan bertujuan untuk menjaga kepentingan komunikator dengan komunikan agar merasa senang, tentram, terlindungi tanpa ada pihak lain yang dirugikan kepentingannya dan perbuatan yang dilakukan sesuai dengan adat kebiasaan yang berlaku serta tidak bertentangan dengan hak asasi. Secara umum tata cara pergaulan, aturan perilaku, adat kebiasaan manusia dalam bermasyarakat dan menentukan nilai baik dan nilai tidak baik disebut sebagai etika (Haryatmoko, 2007).

Etika berasal dari kata ethikus dan dalam bahasa Yunani disebut ethicos yang berarti kebiasaan norma-norma, nilai-nilai, kaidah-kaidah, ukuran-ukuran baik dan buruk tingkah laku manusia (Diknas, 2005). Sedangkan komunikasi merupakan penanda adanya interaksi antara anggota masyarakat, karena komunikasi selalu melibatkan setidaknya dua orang. Dalam interaksi selalu diperlukan norma-norma atau aturan-aturan yang berfungsi untuk pengendalian atau kontrol sosial. Tujuannya untuk menciptakan masyarakat yang tertib. Salah satu bentuk untuk mewujudkan tertibnya masyarakat adalah adanya etika, yakni filsafat yang mengkaji baik buruknya suatu tindakan yang dilakukan manusia (Kismiyati, 2010). Jadi, etika komunikasi adalah norma, nilai, atau ukuran tingkah laku baik dalam kegiatan komunikasi pada suatu masyarakat (Haryatmoko, 2007).

Nilsen mengungkapkan bahwa untuk mencapai etika komunikasi perlu diperhatikan sifat-sifat di antaranya penghormatan terhadap seseorang sebagai person tanpa memandang umur, status, atau hubungannya dengan pembicara, penghormatan terhadap ide, perasaan, maksud dan integritas orang lain, sikap suka memperbolehkan, keobjektifan, dan keterbukaan pikiran yang mendorong kebebasan berekspresi, penghormatan terhadap bukti dan pertimbangan yang rasional terhadap berbagai alternatif dan terlebih dahulu mendengarkan dengan cermat serta berhati-hati sebelum menyatakan persetujuan atau ketidaksetujuan (Nugroho, 2010). Jadi, secara sederhana etika komunikasi dapat dipahami sebagai suatu pedoman bertindak atas dasar moralitas yang berkaitan erat dengan adat kebiasaan, norma, nilai, dan kaidah yang berkembang dalam kehidupan masyarakat. Sehingga diharapkan penerapannya dalam proses komunikasi di media sosial dapat mencegah dampak negatif penggunaan media sosial.

\section{Kesalehan Virtual}

Umat manusia saat ini bisa dikatakan telah sampai pada penjelajahan global, sebuah petualangan jagat alam raya maya yang melampaui realitas (hiper-realitas) (Hadi, 2005). Baudrillard mengungkapkan bahwa hiperrealitas sebagai suatu proses yang mengarah pada hancurnya batasan antara media dan dunia sosial, sehingga berita dan hiburan melebur satu sama lain dan televisi menjadi dunia. Televisi mensimulasikan hidup nyata dan tidak terlalu mempresentasikan dunia sebagaimana ia mengeksekusi dirinya sendiri (Barker, 2006).

Secara etimologis, kata saleh berasal dari bahasa Arab shalih yang berarti terhindar dari kerusakan atau keburukan. Amal saleh berarti amal atau perbuatan yang tidak merusak atau mengandung unsur kerusakan. Maka orang 
saleh berarti orang yang terhindar dari kerusakan atau hal-hal yang bersifat buruk. Yang dimaksud dalam hal ini tentu saja perilaku dan kepribadiannya, yang mencakup kata, sikap, perbuatan, bahkan pikiran dan perasaannya. Tak hanya itu, dalam kamus al-Mu'jam al-Wasith kata shaluha sebagai akar kata shalih juga berarti bermanfaat. Dengan menggabungkan dua makna ini, maka orang saleh berarti orang yang perilaku dan kepribadiannya terhindar dari hal-hal yang merusak, dan di sisi lain membawa manfaat bagi lingkungan sekitarnya. Dengan kualitas tersebut, ia menjadi sosok harapan dan teladan bagi orang-orang di sekitarnya.

Dalam KBBI kesalehan termasuk dalam kelas kata benda (nomina) yang berarti ketaatan (kepatuhan) dalam menjalankan ibadah; kesungguhan dalam menunaikan ajaran agamanya tercermin pada sikap hidupnya. Jadi, dapat disimpulkan bahwa kesalehan adalah ketaatan (kepatuhan) dalam menjalankan ibadah atau suatu kesungguhan menjalankan agama. Sedangkan kata virtual menurut KBBI termasuk dalam kelas kata sifat (adjektiva) yang berarti (secara) nyata: demokrasi dalam arti virtual. Dalam hal ini, harus dipahami makna kata dalam kurung tersebut yang sangat penting, karena makna kata 'secara' dapat disamakan dengan 'seolah-olah'. Jadi, dapat dipahami bahwa virtual adalah 'maya' atau 'seolah-olah' nyata.

Hal tersebut sesuai dengan yang diungkapkan oleh Werner bahwa virtual adalah cyberspace/ruang maya. Cyberspace berasal dari kata cybernetics dan space. Cyberspace sendiri pertama kali diperkenalkan oleh William Gibson yang menyebutkan bahwa dunia maya (cyberspace) adalah realita yang terhubung secara global, didukung oleh komputer, berakses komputer, multidimensi, artifisial, atau virtual (Severin, 2001).

Berdasarkan beberapa definisi-definisi yang sudah dipaparkan di atas, maka dapat dipahami bahwa kesalehan virtual adalah ketaatan (kepatuhan) dalam menjalankan ibadah atau suatu kesungguhan dalam menjalankan agama yang tersaji dalam suatu proses komunikasi di komunitas virtual yang terhubung secara global, serta didukung oleh berbagai media di antaranya komputer, televisi, maupun smartphone.

\section{Media Sosial}

Media baru atau new media merupakan media yang menawarkan digitalitation, convergence, interactivity, dan development of network dalam pembuatan pesan dan penyampaian pesan. Kemampuan media baru menawarkan interaktifitas ini memungkinkan pengguna dari media baru memiliki pilihan informasi apa yang dikonsumsi, sekaligus mengendalikan keluaran informasi yang dihasilkan serta melakukan pilihan-pilihan yang diinginkan pengguna. Kemampuan menawarkan suatu interactivity inilah yang merupakan konsep sentral dari pemahaman tentang media baru (Flew, 2002). Menurut Watie, media sosial yang dikenal juga sebagai jejaring sosial merupakan bagian dari media baru (Watie, 2011).

Media sosial adalah fitur berbasis website yang dapat membentuk jaringan serta memungkinkan orang untuk berinteraksi dalam sebuah komunitas. Pada media sosial seseorang dapat melakukan berbagai bentuk pertukaran, kolaborasi, dan saling berkenalan dalam bentuk tulisan, visual maupun audiovisual. Misalnya, Facebook, Twitter, dan Instagram (Puntoadi, 2011). Sedangkan menurut Andreas, media sosial adalah sebuah kelompok aplikasi berbasis internet yang membangun di atas dasar ideologi dan teknologi, dan yang memungkinkan penciptaan serta pertukaran user-generated content (Cahyono, 2016). Sementara itu, Meike menjelaskan bahwa kata media sosial sebagai konvergensi antara komunikasi personal dalam arti saling berbagi di antara individu (to be share one-to-one) dan media publik untuk berbagi kepada siapa saja tanpa ada kekhususan individu (Setiadi, 2016). Intinya, media sosial adalah media online yang memungkinkan bagi pengguna untuk berpartisipasi, berbagi, dan menciptakan isi (Herlanti, 2004).

Media sosial dalam penggunaannya membuat komunikasi interpersonal dan komunikasi massa melebur menjadi satu. Saat seseorang mengunggah sesuatu kemudian ditanggapi pihak lain, lalu terjadi interaksi, maka komunikasi interpersonal terjadi. Pada saat yang sama, saat seseorang mengunggah sesuatu, apa yang diunggahnya dapat dilihat dan dinikmati khalayak banyak, sehingga pada saat yang sama komunikasi massa juga terjadi. Sebab, komunikasi massa tidak mensyaratkan adanya keterlibatan aktif semua pihak (Watie, 2011). 
Menurut Nasrullah (2015) terdapat enam karakteristik dari media sosial yang membedakannya dengan media lainnya sebagai berikut. Pertama, jaringan (network), jaringan adalah infrastuktur yang menghubungkan antara komputer dengan perangkat keras lainnya. Koneksi ini diperlukan karena komunikasi dapat terjadi jika antar komputer terhubung, termasuk di dalamnya perpindahan data. Kedua, informasi (informations), informasi menjadi entitas penting di media sosial dikarenakan pengguna media sosial mengkreasikan representasi identitasnya, memproduksi konten, dan melakukan interaksi berdasarkan informasi. Ketiga, arsip (archive), bagi pengguna media sosial, arsip menjadi sebuah karakter yang menjelaskan bahwa informasi telah tersimpan dan dapat diakses kapan pun dan melalui perangkat apa pun. Keempat, interaksi (interactivity), media sosial membentuk jaringan antara pengguna yang tidak sekedar memperluas hubungan pertemanan atau pengikut (follower) semata, akan tetapi harus dibangun dengan interaksi antara pengguna tersebut. Kelima, simulasi sosial (simulation of society), media sosial memiliki karakter sebagai medium berlangsungnya masyarakat (society) di dunia virtual. Media sosial memiliki keunikan dan pola yang dalam banyak kasus berbeda dan tidak dijumpai dalam tatanan masyarakat yang real.

Keenam, konten oleh pengguna (user-generated content), di media sosial konten sepenuhnya milik dan berdasarkan kontribusi pengguna atau pemilik akun. UGC merupakan relasi simbiosis dalam budaya media baru yang memberikan kesempatan dan keleluasaan pengguna untuk berpartisipasi. Hal ini berbeda dengan media lama (tradisional) di mana khalayaknya sebatas menjadi objek atau sasaran yang pasif dalam distribusi pesan (Nasrullah, 2015).

Media sosial sangat mendukung kesalehan secara virtual dikarenakan media sosial merupakan wadah pengungkapan diri atau identitas terhadap agama yang diyakini, seperti Islam misalnya yang di dalamnya memuat berbagai ritual ibadah. Kemudian pada akhirnya foto yang diunggah, pesan status yang dibuat, profil diri yang ditulis, dan bahkan grup apa yang diikuti dapat ditafsirkan sebagai upaya individu dalam hal ini seorang muslim untuk menunjukkan jati dirinya. Kemudian apakah setiap identitas yang dibangun itu menunjukkan atau mencerminkan kesalehan individu di dunia nyata, ataukah hanya sebatas wacana identitas yang ada di media sosial (Nasrullah, 2011).

\section{Perilaku Bermedia Masyarakat}

Kata perilaku secara etimologi adalah tanggapan atau reaksi individu terhadap rangsangan lingkungan (Depdikbud, 1991). Secara terminologi perilaku menurut Sarwono adalah segala sesuatu yang dilakukan oleh satu individu dengan individu lainnya yang bersifat nyata, dalam artian adalah semua reaksi yang dilakukan seseorang yang dapat diamati (Nahlawi, 1992). Kemudian bermedia adalah kata kerja yang kata dasarnya media, kata media berasal dari bahasa Latin, yakni medius yang artinya tengah, perantara atau pengantar. Kata media, merupakan bentuk jamak dari kata "medium", yang secara etimologi berarti perantara atau pengantar. Dalam artian, media merupakan perantara/penghubung yang terletak antara dua pihak, atau sarana komunikasi seperti koran, majalah, radio, televisi, film, poster, dan spanduk (Dagun, 2006).

Kemudian masyarakat dalam istilah bahasa Inggris adalah society yang berasal dari kata latin socius yang berarti kawan. Istilah masyarakat berasal dari kata bahasa Arab syakara yang berarti (ikut serta berpartisipasi). Dalam artian, masyarakat adalah sekumpulan manusia yang saling bergaul, dalam istilah ilmiah adalah saling berinteraksi. Suatu kesatuan manusia dapat mempunyai prasarana melalui warga-warganya dapat saling berinteraksi. Definisi lain, masyarakat adalah kesatuan hidup manusia yang berinteraksi menurut suatu sistem adat istiadat tertentu yang bersifat kontinyu, dan terikat oleh suatu rasa identitas bersama. Kontinuitas merupakan kesatuan masyarakat yang memiliki keempat ciri yaitu interaksi antara warga-warganya, adat istiadat, kontinuitas waktu, dan rasa identitas kuat yang mengikat semua warga (Koentjaraningrat, 2009).

Dari beberapa definisi di atas, dapat dipahami bahwa perilaku bermedia masyarakat adalah suatu tanggapan atau reaksi terhadap rangsangan sarana komunikasi seperti koran, majalah, radio, televisi, film, internet, poster, dan spanduk, yang dilakukan oleh sekumpulan manusia yang saling bergaul atau saling berinteraksi satu sama lain. Dalam karya tulis ilmiah ini akan lebih banyak membahas perilaku 
bermedia masyarakat dalam media baru (new media). Media baru merupakan media yang menawarkan digitalisasi, konvergensi, dan interaktif terkait pembuatan pesan dan penyampaian pesannya (Flew, 2002).

Munculnya realitas virtual, komunitas virtual, dan identitas virtual merupakan fenomena yang banyak muncul seiring dengan hadirnya media baru. Fenomena ini muncul dikarenakan media baru memungkinkan penggunanya untuk menggunakan ruang seluas-luasnya pada media baru, memperluas jaringan seluas-luasnya, serta menunjukkan identitas yang lain dengan yang dimiliki pengguna tersebut di dunia nyata (Flew, 2002). Media sosial atau yang dikenal juga sebagai jejaring sosial merupakan bagian dari media baru. Selain itu, media sosial memiliki kekuatan sosial yang sangat mempengaruhi opini publik yang berkembang di masyarakat. Inilah kemudian alasan mengapa media ini disebut media sosial bukan media massa.

\section{METODE PENELITIAN}

Penelitian ini menggunakan metode penelitian kualitatif dengan pendekatan deskriptif. Oleh karena itu, teknik pengumpulan data yang digunakan ialah observasi dan dokumentasi. Hasil observasi dan dokumen yang telah berhasil dikumpulkan tersebut kemudian dianalisis, dibandingkan, dan dipadukan sehingga terbentuk sebuah hasil kajian yang sistematis, padu, dan utuh. Penelitian ini dilakukan pada media sosial Twitter dan Instagram. Media sosial Twitter dipilih dikarenakan keunggulannya dalam proses interaksi secara langsung dan eksklusif. Sedangkan media sosial Instagram dipilih untuk melengkapi jenis perilaku bermedia sosial masyarakat yang berkembang, mengingat Instagram termasuk media sosial yang cukup populer digunakan di Indonesia. Sementara itu, data didapatkan berdasarkan akun-akun media sosial yang berinteraksi dengan akun peneliti serta dalam jangkauan akun peneliti.

Metode pengumpulan data penelitian ini diperoleh melalui observasi dan dokumentasi akun media sosial tertaut, kemudian data-data yang terkumpul selanjutnya akan diolah oleh penulis sesuai kebutuhan. Sehingga dalam hal ini, analisis data kualitatif adalah usaha yang dilakukan dengan jalan bekerja dengan data- data, mengorganisasikan data, memilah data menjadi satu kesatuan utuh yang dapat dikelola, dipadukan, mencari dan menemukan pola, menemukan apa yang penting dan apa yang dapat dipelajari. Kemudian memutuskan apa yang sekiranya dapat disampaikan kepada orang lain dengan baik serta mudah untuk dipahami.

\section{HASIL DAN PEMBAHASAN}

\section{Perilaku Bermedia Sosial Masyarakat}

Perkembangan teknologi informasi dewasa ini justru menggiring masyarakat global ke arah pergeseran nilai sosial. pergeseran nilai sosial ditandai dengan transparasi sosial, yakni suatu kondisi lenyapnya kategori sosial, batas sosial, hierarki sosial yang sebelumnya membentuk suatu masyarakat. Berikutnya jaringan informasi menjadi bersifat transparan dan virtual ketika tidak ada lagi kategori-kategori moral yang mengikatnya dan ukuran-ukuran nilai yang membatasinya. Sehingga orang yang terjebak dalam proses komunikasi di dalam dunia virtual dapat tenggelam di dalamnya dan terbawa arus gaya komunikasi yang ada, hingga tidak jarang bisa seolah menjadi sosok lain, yang jauh berbeda dengan dunia nyatanya dalam keseharian (Piliang, 2004).

Pada era saat ini, aktivitas jaringan informasi dan komunikasi yang dilakukan oleh masyarakat di seluruh penjuru dunia dapat dibilang masif dan intensif. Ada banyak motif dan tujuan yang menjadi dasar masyarakat dalam mengakses layanan jaringan informasi, khususnya media baru. Berikut ini, penulis paparkan macam-macam perilaku bermedia sosial masyarakat berdasarkan hasil temuan penelitian, dalam temuan ini dapat diungkapkan bahwa penggunaan media baru yang relatif menyita perhatian berbagai pihak antara lain, yakni swafoto (selfie), cyberwar, belanja daring, personalisasi diri pengguna, dan budaya share.

Pertama, swafoto (selfie), salah satu fenomena dalam kemajuan teknologi informasi, yakni kemunculan media baru, dan budaya cyber salah satunya adalah selfie atau swafoto. Kata ini pun telah resmi menjadi kata baru yang dicantumkan dalam kamus Oxford English Dictionary pada tahun 2013 dan secara sederhana berarti 'foto diri yang disebarluaskan melalui media sosial'. Menurut Jerry Saltz, selfie didefinisikan sebagai potret-diri instan, yang dibuat dengan kamera 
telepon pintar dan dengan segera disebarluaskan atau dibagikan melalui internet sebagai bentuk komunikasi visual instan mengenai di mana seseorang berada, apa yang dilakukan, apa yang dipikirkan, dan siapa yang seseorang pikir melihatnya (Nasrullah, 2015).

Secara historis, swafoto muncul dan dapat dilihat hampir bertepatan dengan adanya perangkat fotografi di telepon selular. Lain halnya dengan foto digital menggunakan DSLR atau jenis kamera lainnya, dengan menggunakan telepon selular, foto yang diambil dapat langsung diunggah di media sosial saat itu juga. Realitas ini membawa pada sebuah kenyataan bahwa pada awalnya, pengguna atau seseorang ingin membagikan momen atau aktivitas mereka bersama teman-temannya di jejaring media sosial. Kenyataan berikutnya, foto diri yang ditampilkan di media sosial dalam rangka eksistensi diri dan upaya mempertontonkan apa yang telah dicapai pengguna di luar jaringan. Karena itu, foto diri tidak bisa sekedar dilihat dari aspek wajah, ekspresi, dan gaya. Akan tetapi, juga harus melibatkan suasana, momen, bangunan, tempat, dan lingkungan yang menjadi latar dari sebuah foto diri (Nasrullah, 2015).

Kedua, cyberwar, fenomena cyberwar ini bisa dijumpai dalam kasus fanatisme pendukung Jokowi dan Prabowo dalam kontestasi pemilu 2019. Pada saat itu, kedua kelompok saling berlomba mengusung masing-masing calon. Atmosfer semangat hingga gaduh yang disebabkan oleh opini maupun pemberitaan terkait figur Jokowi atau Prabowo, menjadi warna yang tidak dapat dielakkan. Perwujudan perilaku kelompok pendukung Jokowi dan Prabowo uniknya terjadi secara masif di ruang virtual atau berkutat dalam konstelasi media sosial yang terhimpun dalam komunitaskomunitas tertentu. Ajang debat kusir dan adu berita hoax seolah menjadi paket menu yang biasa dijumpai dalam arus notifikasi media sosial, seperti Instagram, Facebook, dan Twitter. Selain berita atau status dukungan untuk mereka.

Smelser mengungkapkan bahwa terdapat beberapa faktor penentu perilaku kolektif, antara lain yakni faktor struktur situasi sosial yang memudahkan terjadinya perilaku kolektif, seperti keberagamaan agama, suku, ideologi, dan ras dalam suatu wilayah tertentu. Kemudian juga kesenjangan, ketidakserasian antara kelompok sosial, etnik, agama, dan lain sebagainya yang membuka peluang bagi terjadinya berbagai macam bentuk ketegangan. Semakin besar ketegangan struktural, maka semakin besar pula peluang terjadinya perilaku kolektif. Semua ini dapat terjadi disebabkan oleh beberapa hal di antaranya desas-desus yang dengan sangat mudah dipercaya kebenarannya dan kemudian disebarluaskan, faktor penunjang kecurigaan dan kecemasan yang dikandung masyarakat, kemudian perwujudan perilaku kolektif yang digiring oleh pimpinan, baik untuk bergerak menjauhi situasi berbahaya atau untuk mendekati orang yang dianggap sasaran tindakan (Krahe, 2005).

Ketiga, belanja daring, gaya hidup berbelanja masyarakat Indonesia selalu berubah seiring dengan perkembangan zaman, terlebih dewasa ini tren belanja secara elektronis yang diadaptasikan ke dalam berbagai media. Hal tersebut dimulai dari daya tarik banner iklan, video tutorial, diskon, pembayaran melalui rekening bersama hingga sistem pembayaran sesudah barang diterima (cash on delivery). Kesuksesan perusahaan dalam memanfaatkan $e$ commerce dalam memasarkan produknya diikuti dengan ironi pengaburan realitas di kalangan masyarakat. Situs belanja daring yang populer di Indonesia saat ini antara lain Tokopedia, Lazada, Olx, Bukalapak, Shopee, Jd.id, dan lain sebagainya.

Bagi konsumen, belanja daring akan sangat tinggi jika masyarakat merasa puas akan kualitas jasa dari sistem penjualan daring pada situs terkait. Kepuasan pelanggan saat berbelanja daring serta kepuasan pelanggan setelah melakukan pembelian menjadi indikator di mana suatu situs toko daring dapat mempertahankan pelanggannya dengan cara meningkatkan minat berbelanja kembali pada situs terkait (Irmawati, 2011).

Keempat, personalisasi diri pengguna. Penggunaan sosial media yang meluas telah memberikan banyak sekali fenomena yang menarik misalnya saja maraknya akun-akun pengguna yang dengan sengaja memasang foto profil bukan dirinya, tanpa foto profil, dan tanpa identitas yang jelas. Selain akun pengguna tanpa identitas yang jelas, ironi perilaku pengguna media sosial juga tercermin dari upaya-upaya mereka untuk merekonstruksi identitas melalui tulisan status atau distribusi tautan halaman 
tertentu yang sebenarnya hanya untuk menjelaskan kepada khalayak mengenai siapa dan bagaimana atau malah justru sebaliknya, tidak mewakili identitas pengguna sama sekali (Nasrullah, 2015).

Dengan demikian, kesadaran akan sesuatu yang nyata di benak para pengguna media sosial semakin terdegradasi dan tergantikan realitas maya. Kondisi ini disebabkan oleh imajinasi yang ditampilkan media secara kontinu hingga pada akhirnya masyarakat seolah berada di antara realitas dan ilusi disebabkan tanda yang ada pada media seakan-akan telah terputus dari realitas. Dalam artian, media sosial telah menjadi realitas itu sendiri. Dan bahkan, apa yang ada di dalamnya justru lebih nyata dan aktual.

Kelima, budaya share. Dewasa ini, banyak bermunculan situs atau blog yang tidak jelas. Pengelolanya tidak segan-segan menggunakan atribut provokatif, seperti kata 'sebarkanlah' atau kata-kata bombastis sejenisnya. Pesan yang sering dipakai adalah "Share ke yang lain, bagikan, atau simpan." Terkadang disertai ancaman seperti surat berantai pada masa lalu. Apabila berita tidak disebarkan, maka masyarakat disumpahi akan mendapat petaka, bencana, dan duka lara.

Fenomena budaya share makin menggila saatsaat tahun politik seperti saat ini. Beberapa figur ternama pendukung capres tertentu dengan atau tanpa sengaja memelintir berita, mengomentari lalu menjatuhkan lawan politiknya. Pola-pola pemberitaan hoax pun relatif selalu sama, membuat judul bombastis untuk menarik minat baca. Terkadang antara judul dan isi berita tidak sinkron sama sekali. Celakanya, banyak pengguna media di negeri ini yang malas membaca. Mereka cenderung mudah terprovokasi oleh judul yang tampak menarik dan langsung membagikan tautan laman tertentu tanpa menelaah terlebih dahulu.

Jadi, beberapa macam perilaku bermedia masyarakat yang telah dipaparkan di atas tentu sangat terkait dengan etika komunikasi dan kesalehan virtual. Misalnya, ketika swafoto pengguna dapat membatasi dirinya dengan nilai dan norma yang berlaku sehingga tidak sampai membagikan swafoto yang justru merugikan lawan komunikasinya. Berikutnya, adanya fenomena cyberwar tentu mengindikasikan bahwa belum adanya kesalehan virtual yang tercipta. Dalam artian, etika komunikasi belum diterapkan terkait dengan hal ini. Berikutnya, dalam perilaku belanja daring, etika komunikasi bisa digunakan untuk mengontrol proses transaksi agar tidak ada pihak yang merasa ditipu atau dirugikan, sehingga akan tercipta kesalehan virtual. Sedangkan dalam perilaku personalisasi diri pengguna, banyak ditemukan akun-akun anonim atau dengan identitas yang tidak jelas di media sosial yang justru banyak meresahkan dan mengganggu standar etika komunikasi yang baik di media sosial. Sementara itu, budaya share juga perlu penerapan etika komunikasi yang baik, agar para pengguna media sosial tidak sembarangan membagikan konten-konten yang merugikan atau meresahkan masyarakat, sehingga tidak tercipta yang namanya kesalehan virtual.

\section{Etika Komunikasi Sebagai Kontrol Kesalehan Virtual di Era Digital}

Berdasarkan pengamatan penulis ditemukan bahwa proses komunikasi di media sosial sering dilakukan dengan menggunakan bahasa yang tidak baku. Salah satu penyebabnya yakni di dunia virtual sering tidak jelas siapa lawan komunikasinya dan di mana posisinya, meskipun banyak juga orang yang sudah berinteraksi dan bertemu di dunia nyata, dan berlanjut komunikasi di dunia virtual. Bahasa yang digunakan di media sosial bukanlah bahasa resmi sebagaimana menulis artikel ilmiah, makalah, jurnal, skripsi, dan tesis. Sangat sedikit dan hampir tidak ada penggunaan media sosial dalam menulis status sesuai dengan Ejaan Yang Disempurnakan (EYD). Padahal, teknik penulisan yang baku sangat penting dilakukan dikarenakan terkait dengan etika dalam berkomunikasi sesama pengguna media sosial.

Media sosial seolah menjadi tempat menumpahkan cerita dan segala bentuk aktivitas, luapan emosi dalam bentuk tulisan atau foto yang tidak jarang mengesampingkan etika yang ada. Media sosial tidak lagi menjadi media berbagi informasi, namun hanya berbagi sensasi. Apabila kemajuan teknologi tidak dibarengi dengan kemajuan dalam berpikir, maka yang ada kemajuan teknologi tersebut berbanding terbalik dalam hal pola pikir. Dalam kehidupan bersosial di masyarakat, istilah etika seringkali dikaitkan dengan moralitas seseorang. Seseorang yang tidak memiliki etika yang baik seringkali disebut tidak bermoral 
dikarenakan tindakan atau perkataan yang diambil tidak melalui pertimbangan baik dan buruk. Dikarenakan menyangkut pertimbangan akan nilai-nilai baik yang harus dilakukan dan nilai-nilai buruk yang harus dihindari. Tidak adanya filter pertimbangan nilai baik dan buruk merupakan awal dari bencana dalam penggunaan media sosial.

Etika komunikasi dalam implementasinya antara lain dapat diketahui dari komunikasi yang santun. Hal ini merupakan cerminan dari kesantunan kepribadian personal. Komunikasi diibaratkan seperti urat nadi penghubung kehidupan, sebagai salah satu ekspresi dari karakter, sifat atau tabiat seseorang untuk saling berkomunikasi, mengidentifikasikan diri serta bekerja sama. Etika komunikasi tidak hanya berkaitan dengan tutur kata yang baik, melainkan juga harus berangkat dari niat tulus yang diekspresikan dari ketenangan, kesabaran, dan empati individu dalam berkomunikasi. Bentuk komunikasi yang demikian akan menghasilkan komunikasi dua arah yang bercirikan penghargaan, perhatian, dan dukungan secara timbal balik dari pihak-pihak yang berkomunikasi.

Komunikasi yang beretika kini tentu saja menjadi persoalan penting terkait dengan kontrol kesalehan virtual, selain itu juga menjadi persoalan penting dalam penyampaian aspirasi. Dalam keseharian eksistensi penyampaian aspirasi masih sering dijumpai sejumlah hal yang mencemaskan dari perilaku komunikasi yang kurang santun. Etika komunikasi sering terpinggirkan, dikarenakan etika komunikasi belum membudaya sebagai urat nadi kehidupan bermasyarakat dan bernegara. Adapun etika komunikasi yang baik dalam bermedia sosial adalah jangan menggunakan kata kasar, provokatif, porno ataupun sara. Kemudian juga jangan memposting artikel atau status yang bohong, jangan menyalin dan tempel artikel atau gambar yang mempunyai hak cipta, serta memberikan komentar yang relevan (Mursito, 2006).

Dalam al-Qur'an etika komunikasi mencakup beberapa hal di antaranya perkataan yang benar (qaulan sadida), perkataan yang sampai atau membekas (qaulan baligha), perkataan yang baik (qaulan ma'rufa), perkataan yang mulia (qaulan karima), perkataan yang lembut (qaulan layyinan), dan perkataan yang ringan (qaulan maysura). Selain itu juga dalam Islam ada etika komunikasi yang sangat penting yaitu salam yang dapat juga dikatakan sebagai gerbang komunikasi etis. Hal tersebut dikarenakan salah satu etka komunikasi yang dijelaskan al-Qur'an adalah membuka pembicaraan dengan ucapan salam. Kemudian seorang muslim juga harus memuliakan lawan bicaranya dan memulai pembicaraannya dengan salam. Sehingga gaya komunikasi seperti ini akan menghadirkan ketenangan bagi lawan bicara dan memberikan rasa percaya diri kepada pembicara. Selain itu juga komunikan dapat mengetahui bahwa tujuan dari berbicara adalah untuk menyampaikan pesan dengan kelembutan dan niat baik (Rakhmat, 1994).

Berikut ini penulis berikan contoh akun media sosial yang menggunakan etika komunikasi dalam bermedia sosial sehingga akhirnya dapat mengontrol arus kesalehan dalam dunia virtual:

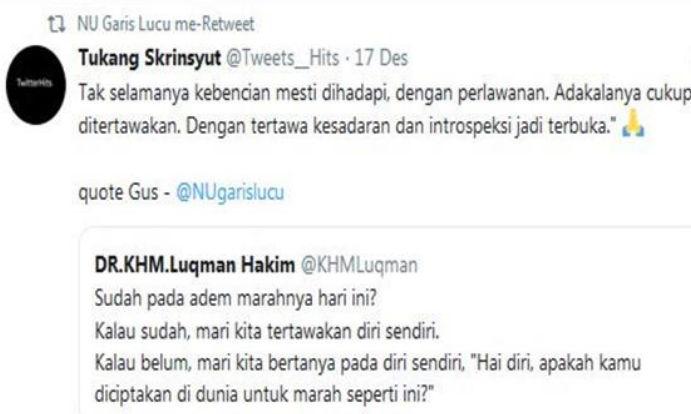

Gambar 1. Contoh penggunaan etika komunikasi di media sosial sebagai kontrol kesalehan virtual

t] NU Garis Lucu me-Retweet

Muhammadiyah Garis Lucu @MuhammadiyahGL · 13 Des

Kalo orang NU main sosmed buat hiburan, Orang Muhammadiyah main sosmed buat lucu-lucuan Gus @NUgarísucu. Sebab di dunia nyata (belakangan ini) pada suka spanengan...

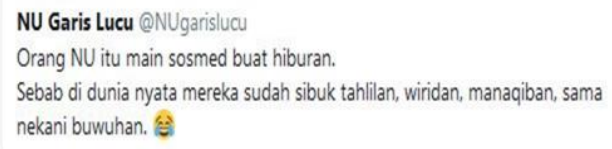

Gambar 2. Contoh penggunaan etika komunikasi di media sosial sebagai kontrol kesalehan virtual

Dua contoh di atas membuktikan bahwa etika dalam berkomunikasi dapat mengontrol kesalehan dalam dunia virtual. Sesuai dengan indikator yang sudah dijelaskan di atas, antara lain perkataan yang benar (qaulan sadida), perkataan yang sampai atau membekas (qaulan baligha), perkataan yang baik (qaulan ma'rufa), perkataan yang mulia (qaulan karima), 
perkataan yang lembut (qaulan layyinan), dan perkataan yang ringan (qaulan maysura).

Jadi, etika komunikasi bukan merupakan kajian filsafat yang mengawang-awang dan sulit dibumikan. Kajian etika komunikasi masuk dalam kajian etika terapan yang bersifat empiris dan bersumber dari fenomena yang benar-benar terjadi di sekitar. Dalam mengontrol kesalehan pada dunia virtual, Habermas menyarankan agar suatu masyarakat termasuk dalam hal ini masyarakat virtual harus sesegera mungkin untuk membangun etika diskursus. Etika diskursus bukanlah kategori-kategori imperatif, melainkan prosedur argumentasi moral. Yakni, suatu justifikasi normatif untuk mencapai kesesuaian akan kepentingan antar anggota (generalizable interest) (Fauzi, 2004).

Etika komunikasi sebagai kontrol kesalehan virtual ini merupakan suatu kondisi dari komunikasi yang nantinya akan menjamin kepada tercapainya sifat-sifat umum akan norma-norma yang bisa diterima, serta menjamin kepada otonomi individu melalui kemampuan emansipatoris sehingga menghasilkan pembentukan kehendak bersama melalui perbincangan rasional. Dengan demikian, etika komunikasi merupakan sebuah upaya yang menurut Habermas dapat digunakan untuk menerjemahkan teori tindakan komunikatif guna menjaga dan menjamin pada terciptanya stabilitas sosial dalam masyarakat yang plural. Dalam artian, realitas masyarakat yang plural tidak lagi bisa mengacu pada suatu klaim nilai atau norma moral tertentu.

Mayarakat virtual yang memiliki perbedaan orientasi nilai tidak dapat terjembatani hasrat dan kepentingannya dalam bermedia sosial, kecuali dengan melakukan tindakan komunikasi. Masyarakat komunikatif yang mengedepankan etika diharapkan dapat mengatasi berbagai konflik dan persoalan perilaku bermedia sosial masyarakat. Ketika masyarakat komunikatif mampu berpikir dewasa dan rasional, maka kesalehan dalam dunia virtual akan berangsur-angsur terwujud. Cara mewujudkan kesalehan virtual tersebut adalah dengan mengkomunikasikan etika diskursus terhadap dunia virtual, baik melalui media resmi maupun tidak resmi yang sengaja dibuat sendiri oleh masyarakat sebagai respon dari apa yang terjadi dalam dunia virtual.

\section{KESIMPULAN}

Dalam hal ini, etika komunikasi secara sederhana dapat dipahami sebagai seperangkat norma, nilai, atau ukuran perilaku baik dalam kegiatan komunikasi dalam suatu masyarakat. Etika komunikasi dapat tercapai dengan memperhatikan penghormatan terhadap seseorang sebagai person tanpa memandang umur, status, atau hubungannya dengan pembicara. Penghormatan terhadap ide, perasaan, maksud dan integritas orang lain, sikap suka memperbolehkan, keobjektifan, dan keterbukaan pikiran yang mendorong kebebasan berekspresi. Selain itu, juga penghormatan terhadap bukti dan pertimbangan yang rasional terhadap berbagai pilihan alternatif, dan terlebih dahulu mendengar dengan cermat serta hati-hati sebelum menyatakan persetujuan dan ketidak setujuan. Berikutnya kesalehan virtual secara sederhana dapat dipahami sebagai ketaatan dalam menjalankan ibadah atau suatu kesungguhan dalam menjalankan agama yang tersaji dalam ruang maya (cyberspace) yang terhubung secara global, serta didukung oleh berbagai media. Sementara itu, perilaku bermedia masyarakat dapat dirangkum menjadi beberapa hal di antaranya swafoto (selfie), cyberwar, belanja daring, personalisasi diri pengguna, dan budaya share.

Etika komunikasi sebagai kontrol kesalehan virtual ini merupakan suatu kondisi dari komunikasi yang nantinya diharapkan dapat menjamin pada tercapainya sifat-sifat umum akan norma-norma yang dapat diterima, serta menjamin pada otonomi individu melalui kemampuan emansipatoris sehingga menghasilkan pembentukan kehendak bersama melalui perbincangan rasional. Dengan demikian, etika komunikasi merupakan sebuah upaya untuk menerjemahkan teori tindakan komunikatif guna menjaga dan menjamin pada terciptanya stabilitas sosial dalam masyarakat yang plural. Sehingga implementasi etika komunikasi diperlukan dalam mengontrol aktivitas atau perilaku bermedia masyarakat di era digital, guna menciptakan kesalehan virtual. Yakni, suatu kondisi di mana para pengguna 
media sosial bisa mengamalkan atau menjalankan nilai-nilai dari agama untuk ditransformasikan di ruang virtual demi terciptanya stabilitas dan kedamaian masyarakat virtual.

\section{REFERENSI}

Barker, Chris. (2006). Cultural Studies: Teori dan Praktik. Yogyakarta: Kreasi Wacana.

Cahyono, Anang Sugeng. (2016). Pengaruh Media Sosial terhadap Perubahan Sosial Masyarakat di Indonesia. Jurnal Publicana 09 (01): 140-157 (https://www.jurnalunita.org/index.php/publiciana/article/view/ 79), [Online]

Dagun, Save M. (2006). Kamus Besar Ilmu Pengetahuan. Jakarta: LKPN.

Depdikbud. (1991). Kamus Besar Bahasa Indonesia. Jakarta: Balai Pusataka.

Diknas. (2005). KBBI Edisi Ketiga. Jakarta: Balai Pustaka.

Fahmi, Abu Bakar. (2011). Mencerna Situs Jejaring Sosial. Jakarta: Elex Media Komputindo.

Fauzi, Ibrahim Ali. (2004). Seri Tokoh Filsafat Jurgen Habermas. Jakarta: Mizan.

Flew, Terry. (2002). New Media: An Introduction. New York: Oxford University Press.

Hadi, Astar. (2005). Matinya Dunia Cyberspace: Kritik Humanis Mark Slouka terhadap Jagat Maya. Yogyakarta: LKiS.

Haryatmoko. (2007). Etika Komunikasi. Jakarta: Kanisius.

Herlanti, Yanti. (2004). BlogQuest: Pemanfaatan Media Sosial pada Pembelajaran Sains Berbasis Sosiosaintifik untuk Mengembangkan Keterampilan Berargumentasi dan Literasi Sains. Bandung: UPI.

Ihsani, A. Fikri Amiruddin; Syakuuroo S.K, Abdan. (2020). The Implementation of Islamic Communication Ethics in The Social Actions of Netizens on Social Media of Twitter. Religia 23 (02): 170-188 (http://ejournal.iainpekalongan.ac.id/index.php/Reli gia/article/view/2087), [Online]

Irmawati, D. (2011). Pemanfaatan E-commerce dalam Dunia Bisnis. Jurnal Ilmiah Orasi Bisnis 02 (06): 95-112.
Kismiyati. (2010). Filsafat dan Etika. Bandung: Widya Padjajaran.

Koentjaraningrat. (2009). Pengantar Ilmu Antropologi. Jakarta: Rineka Cipta.

Krahe, B. (2005). The Social Psychology of Aggression. Philadelphia: Psychology Press.

Mursito. (2006). Memahami Institusi Media: Sebuah Pengantar. Surakarta: Lindu Pustaka.

Nahlawi, Abd. Rahman. (1992). Prinsip-prinsip dan Metode Pendidikan Islam. Bandung: Diponegoro.

Nasrullah, Rulli. (2015). Teori Media Sosial (Perspektif Komunikasi, Kultur, dan SisioTeknologi). Yogyakarta: Simbiosa Rekatama Media.

Nasrullah, Rulli. (2015). Media Sosial Perspektif Komunikasi, Budaya, dan Sosioteknologi. Bandung: Simbiosa Rekatama Media.

Nasrullah, Rulli. (2011). Konstruksi Identitas Muslim di Media Baru. Jurnal Komunika 05
(02):
221-234
(DOI

10.24090/KOMUNIKA.V5I2.172), [Online]

Nugroho. (2010). Adopting Technology, Transforming Society: The Internet and the Reshaping of Civil Society Activism in Indonesia. International Journal of Emerging Technologies and Society 06 (22).

Nurhaliza, W. O., \& Fauziah, N. (2020). Komunikasi Kelompok dalam Virtual Community. Komunida 10 (01): 18-38 (DOI: https://doi.org/10.35905/komunida.v10i01.1 220), [Online]

Nurudin. (2012). Media Sosial Baru. Yogyakarta: DPPM DIKTI.

Piliang, Yasraf Amir. (2004). Dunia yang Dilipat. Yogyakarta: Jalasutra.

Rakhmat, Jalaluddin. (1994). Islam Aktual: Refleksi Seorang Cendekiawan Muslim. Bandung: Mizan.

Setiadi, Ahmad. (2016). Pemanfaatan Media Sosial untuk Efektifitas Komunikasi. Jurnal $\begin{array}{lllll}\text { Cakrawala } & 16 & \text { (02): } & \text { 1-7 } & \text { (DOI: }\end{array}$ https://doi.org/10.31294/jc.v16i2.1283), [Online]

Severin, Werner J. (2001). Teori Komunikasi: Sejarah, Metode, dan Terapan di Dalam Media Massa. Jakarta: Kencana.

Susanto, Joko. (2016). Etika Komunikasi Islami. $\begin{array}{llll}\text { Jurnal Waraqat } & 01 & \text { (01): } & 1-24\end{array}$ 
Etika Komunikasi Sebagai Kontrol Kesalehan Virtual dalam Perilaku Bermedia Masyarakat di Era Digital

(http://waraqat.assunnah.ac.id/index.php/W $\mathrm{RQ/article/view/28),} \mathrm{[Online]}$

Suseno, Frans Magnis. (1993). Etika Dasar.

Jakarta: Pustaka Filsafat.
Watie, Errika Dwi Setya. (2011). Komunikasi dan Media Sosial. The Messenger 03 (01). 